\title{
PERANAN PEMERINTAHAN TERHADAP IMPLEMENTASI PENANGGULANGAN DAN PENCEGAHAN NARKOBA DI KECAMATAN MARITENGNGAE KABUPATEN SIDENRENG RAPPANG
}

\author{
Andi Muhammad Arifin Nu'mang \\ IImu Pemerintahan, Fakultas IImu Sosial dan IImu Politik Universitas Muhammadiyah Sidenreng Rappang \\ a.muh.arifin43151097f1@gmail.com
}

\begin{abstract}
Abstrak
Tujuan penelitian ini yaitu untuk mengetahui Peranan Pemerintahan Daerah Terhadap Implementasi Peraturan Daerah No 2 Tahun 2014 Tentang Penanggulangan Dan Pencegahan Narkoba Di Kecamatan Maritengngae Kabupaten Sidenreng Rappangdan untuk mengetahui faktor-faktorPeranan Pemerintahan Daerah Terhadap Implementasi Peraturan Daerah No 2 Tahun 2014 Tentang Penanggulangan Dan Pencegahan Narkoba Di Kecamatan Maritengngae Kabupaten Sidenreng Rappang. Populasi dalam penelitian ini adalah keseluruhan masyarakat kecamatan maritengae yang berjumlah 49.556 jiwa. Teknik pengambilan sampel menggunakan rumus Slovin dengan hasil 100 , diambil berdasarkan teknik Probability sampling lebih tepatnya Random sampling. Tipe penelitian ini adalah Deskriptif Kuantitatif. Teknik pengumpulan data yang digunakan dalam penelitian ini adalah observasi, kuesioner, dan dokumentasi. Berdasarkan dari hasil olah kuesioner Peranan Pemerintahan Daerah Terhadap Implementasi Peraturan Daerah No 2 Tahun 2014 Tentang Penanggulangan Dan Pencegahan Narkoba Di Kecamatan Maritengngae Kabupaten Sidenreng Rappang. Peranan pemerintah daerah didapatkan rata-rata persentase sebesar 47,68\% termasuk dalam kategori "Cukup Baik". Implementasi Peraturan daerah rata-rata persentase sebesar $39,7 \%$ dan berada dalam kategori "Kurang Baik". Faktor internal yang memengaruhi peranan pemerintah daerah rata-rata persentase sebesar $31 \%$ dan berada dalam kategori"Kurang Baik". Faktor eksternal memiliki rata-rata persentase 50,6\% dan berada dalam kategori "Cukup Baik".
\end{abstract}

Kata Kunci : Peranan pemerintahan, Implementasi, Peraturan Daerah

\begin{abstract}
The purpose of this study is to determine the Role of Regional Government Towards the Implementation of Regional Regulation No. 2 of 2014 Regarding Drug Prevention and Prevention in the District of Maritengngae Sidenreng Rappang Regency and to determine the factors of the Role of Regional Government Towards the Implementation of Regional Regulation No. 2 of 2014 Regarding Drug Prevention and Prevention In the District of Maritengngae, Sidenreng Rappang Regency. The population in this study was the whole of the maritengae sub-district community, amounting to 49,556 souls. The sampling technique uses the Slovin formula with a result of 100, taken based on the Probability sampling technique, more precisely Random sampling. This type of research is quantitative descriptive. Data collection techniques used in this study were observation, questionnaires, and documentation.Based on the results of the questionnaire on the Role of Regional Government Towards the Implementation of Regional Regulation No. 2 of 2014 concerning Drug Prevention and Prevention in the District of Maritengngae, Sidenreng Rappang Regency. The role of the regional government obtained an average percentage of $47.68 \%$ included in the category of "Good Enough". Implementation of regional regulations averaged a percentage of $39.7 \%$ and was in the "Poor" category. Internal factors that influence the role of local governments are on average a percentage of $31 \%$ and are in the "Poor" category. External factors have an average percentage of 50.6\% and are in the "Good Enough" category.
\end{abstract}

Keywords: The role of government, Implementation, of Regional Regulation 


\section{A. PENDAHULUAN}

Indonesia tidak sedikit pula yang menjadi korban penyalahgunaan narkotika,sebenarnya pemerintah di Indonesia sendiri sudah melakukan upaya seperti membentuk BNN dan BNNP yang bertugas untuk memberantas kasus narkoba. Modernisasi merupakan suatu bentuk perubahan sosial kearah kemajuan suatu masyarakat dan bangsa dengan ciri-ciri pokoknya adalah bahwa modersisasi adalah suatu proses revolusioner, rumit, sistematis, global, jangka panjang, bertahap dan bergerak kedepan/progresif.Dari berbagai aspek tersebut terdapat banyak masalah yang memprihatinkan khususnya menyangkut perilaku sebagian generasi muda kita yang terperangkap padapenyalahgunaan narkotika. Seluruh aspek sosial, budaya, agama, politik, ekonomi, pendidikan, ilmu pengetahuan, dan teknologi menjadi daerah rawan karena terjadinya perubahan-perubahan yang sangat mendasar sehingga memerlukan payung hukum untuk menaunginya, Untuk mengantisipasi dan menanggulangi penyalahgunaan narkoba maka pemerintah daerah Kabupaten Sidenreng Rappang mengeluarkan Peraturan Daerah nomor 2 tahun 2014 tentang pencegahan dan penyalahgunaan narkotika dan psikotropika pada pasal 4 menyatakan bahwa tugas pemerintah daerah dalam pencegahan dan penanggulangan terhadap penyalahgunaan dan peredaran gelap narkotika dan psikotropika adalah:

1. Memberikan layanan serta akses komunikasi, informasi dan edukasi yang benar kepada masyarakat tentang penyalahgunaan narkotika dan psikotropika, melakukan koordinasi lintas lembaga baik dengan lembaga pemerintah, swasta, maupun masyarakat.

2. Memfasilitasi upaya khusus, rehabilitasi medis dan rehabilitasi sosial bagi pecandu narkotika dan psikotropika.

3. Melindungi kepentingan masyarakat luas terhadap resiko bahaya penyalahgunaan narkotika dan psikotropika.

4. Melindungi kepentingan masyarakat luas terhadap resiko bahaya penyalahgunaan narkotika dan psikotropika.

Berdasarkan pengamatan awal yang dilakukan calon peneliti melihat bahwa peredaran dan penyalahgunaan narkoba di Kecamatan Maritengngae masih sangat marak, hal itu di buktikan dari ungkapan satuan narkoba polres sidrap mengungkap sedikitnya 140 kasus peredaran narkotika di Kabupaten Sidrap, Sulawesi Selatan (Sulsel), sepanjang 2018 selain itu banyaknya siswasiswi yang putus sekolah serta memiliki latar belakang pergaulan yang buruk di karenakan penyalahgunaan narkotika dan psikotropika selain itu calon peneliti melihat bahwa ada beberapa anak-anak di bawah umur yang dimanfaatkan sebagai kurir untuk mengantar barang haram tersebut dari tangan ke tangan.

Semakin maraknya peredaran narkoba membuat masyarakat merasa ketakutan jika virus buruk tersebut juga nantinya akan mengancam generasi mereka, maka dari itu di butuhkan upaya pemerintah daerah untuk mengurangi jumlah pengedar dan pengguna narkotika tersebut sesuai dengan peraturan daerah nomor 2 tahun 2014 pasal 5 yang menyatakan bahwa kewenangan pemerintah daerah dalam pencegahan dan penanggulangan terhadap penyalahgunaan narkotika dan psikotropika meliput :

1. Menetapkan pedoman operasional dalam upaya pencegahan dan penanggulangan terhadap penyalahgunaan dan peredaran gelap narkotika dan psikotropika.

2. Fasilitasi pencegahan dan penanggulangan penyalahgunaan narkotika dan psikotropika.

Seharusnya pemerintah daerah Kabupaten Sidenreng Rappang mampu menjalankan perannya dalam hal penanggulangan narkoba sesuai dengan amanat peraturan daerah nomor 2 tahun 2014 tentang penanggulangan dan pencegahan terhadap penyalahgunaan narkotika dan psikotropika sehingga masyarakat di Kabupaten Sidenreng Rappang khususnya di Kecamatan Maritengngae merasa aman dari penyalahgunaan narkotika dan psikotropika.sehingga masyarakat di kabupaten sidenreng rappang khususnya di kecamatan maritengngae merasa aman dari penyalahgunaan narkotika dan psikotropika. Kemudian untuk mengetahui bagaimana seharusnya peranan pemerintah daerah dapat di tinjau dari teori yang dikemukakan oleh (Gitosaputro, 2015)yaitu terdapat beberapa peranan yang seharusnya di mainkan oleh agen perubahan tersebut beberapa peranan tersebut yaitu; (1). Sebagai pemecahan masalah(Problem 
solver), (2). Fasilitator, (3). Penghubung antara sistem, (4). Motivator, (5). Komunikator Maka berdasarkan uraian permasalahan di atas maka calon peneliti dapat merumuskan judul dalam rancangan penelitian ini yaitu Peranan Pemerintahan Daerah terhadap Implementasi Peraturan Daerah No 2 Tahun 2014 tentang Penanggulangan dan Pencegahan Narkoba Di Kecamatan Maritengngae Kabupaten Sidenreng Rappang dengan tujuan untuk mengetahui Peranan Pemerintahan Daerah Terhadap Implementasi Peraturan Daerah No 2 tahun 2014 tentang penanggulangan dan pencegahan Narkoba di Kecamatan Maritengngae Kabupaten Sidenreng Rappang dan untuk mengetahui Faktor apa yang memengaruhi Peranan Pemerintahan Daerah terhadap Implementasi Peraturan Daerah No 2 Tahun 2014 tentang Penanggulangan dan Pencegahan Narkoba di Kecamatan Maritengngae Kabupaten Sidenreng Rappang.

\section{Konsep Peranan}

Peran menurut(Sugiyono, 2009)adalah proses dinamis kedudukan (status) peran merupakan aspek dinamis dari kedudukan (status) yang dimiliki oleh seseorang, sedangkan status merupakan sekumpulan hak dan kewajiban yang dimiliki seseorang apabila seseorang melakukan hak-hak dan kewajiban sesuai dengan kedudukannya, maka ia menjalankan suatu fungsi.Narwoko (2006 : 159) peranan dinilai lebih banyak menunjukkan suatu proses dari fungsi dan kemampuan mengadaptasi diri dalam lingkungan sosialnya, dalam pembahasan tentang aneka macam peranan yang melekat pada individu-individu dan kelompokkelompok dalam masyarakat dengan adanya beberapa pertimbangan sehubungan dengan fungsinya. Hakekatnya peran juga dapat dirumuskan sebagai suatu rangkaian perilaku tertentu yang ditimbulkan oleh suatu jabatan tertentu, kepribadian seseorang juga mempengaruhi bagaimana peran itu harus dijalankan, peran yang dimainkan pada hakekatnya tidak ada perbedaan, baik yang dimainkan/diperankan pimpinan tingkat atas, menengah maupun bawah akan mempunyai peran yang sama,peran merupakan aspek yang dinamis dari kedudukan seseorang, apabila seseorang melaksanakan hak-hak dan kewajibannya sesuai dengan kedudukannya maka orang yang bersangkutan menjalankan suatu peranan, untuk memberikan pemahaman yang lebih jelas ada baiknya terlebih dahulu kita pahami tentang pengertian peran (Soekanto S. , 2012 ) Apabila seseorang melaksanakan hak dan kewajibannya sesuai dengan kedudukannya, dia menjalankan suatu peranan, perbedaan antara kedudukan dengan peranan adalah untuk kepentingan ilmu pengetahuan, keduanya tidak dapat dipisah-pisahkan karena yang satu tergantung pada yang lain dan sebaliknya, mereka menyatakan bahwa peran itu"melibatkan pola penciptaan produk sebagai lawan dari perilaku atau tindakan"

Gitosaputro (2015) mengemukakan bahwa beberapa peranan yang seharusnya dimainkan oleh agen perubahan dalam kegiatan pengembangan masyarakat yaitu :

a. Peranan Sebagai Pemecah Masalah (Problem Solving)

Seseorang agen perubahan seharusnya bisa berperan dalam membantu mencari jalan keluar atau pemecahan masalah yang dihadapi oleh masyarakat, masalah pada dasarnya merupakan hal yang sangat sering ditemui dalam kehidupan sehari-hari. Masalah dapat terjadi pada berbagai aspek kehidupan manusia, kemampuan pemecahan masalah adalah kemampuan seseorang untuk menemukan solusi melalui suatu proses yang melibatkan pemerolehan dan pengorganisasian informasi.

b. Peranan Sebagai Fasilitator

Sebagai fasilitator, seseorang agen pembaharu harus memahami kondisi dan situasi masyarakat setempat, sehingga apabila mereka menghadapi atau berhadapan dengan pihak lain tidak lagi merasa minder.

c. Peranan Sebagai Penghubung Antar Sistem

Peran agen sebagai penghubung antar sistem mengacu pada peran seorang komunikator, masyarakat sebagai suatu sistem akan selalu berhadapan dengan pihak lain sebagai bagian sistem yang berbeda dengan sistem masyarakat.

d. Peranan Sebagai Motivator

Motivasi merupakan dorongan yang menyebabkan seseorang melakukan sesuatu, motivasi dapat berasal dari dalam diri (internal) atau dari luar (eksternal), dengan demikian peranan 
agen perubahan sebagai motivator harus mampu mendorong seseorang untuk melakukan sesuatu tindakan (perbuatan), serta mengarahkan tindakan untuk mencapai tujuan, salah satu faktor yang mempengaruhi keberhasilan satu instansi adalah terhadap mengolah sumber daya manusia, motivasi berasal dari kata latin movere yangberarti dorongan atau daya penggerak.

e. Sebagai Komunikator

$$
\text { Agen perubahan sebagai }
$$

komunikator harus mampu menyampaikan pesan-pesan pembangunan kepada masyarakat, dengan harapan masyarakat mau dan mampu menerapkan pesan tersebut sesuai dengan harapan agen perubahan. Oleh karenanya agen pembaharu harus menguasai teknik komunikasi yang baik, komunikator harus mampu meramu pesan pembangunan kedalam bahasa yang dimengerti oleh masyarakat.

\section{Faktor yang Mempengaruhi Peranan}

Faktor-faktor yang mempengaruhi peranan pemerintah menurut Pamudi (JurnalDarma 2019) dapat di identifikasi meliputi dua faktor yaitu:

a. Faktor internal terdiri dari aspek sumber daya manusia atau aparat pelaksana yang masih kurang baik secara kualitas maupun kuantitasnya, ketersediaan sarana dan prasarana kerja yang belum memadai, rendahnya kualitas SDM aparat pemerintah kecamatan yang rata-rata hanya tamat sampai SMA, faktor pendanaan yang tersedia bagi organisasi bersangkutan yang masih minim untuk dapat digunakan dalam pengelolaan organisasi serta sikap camat yang terkesan lebih mementingkan orang lain bila terdapat proyek untuk pembangunan.

b. Faktor eksternal yang menjadi penghambat adalah partisipasi masyarakat dalam mentaati aturan, partisipasi masyarakat adalah keikutsertaan masyarakat baik dalam proses mengidentifikasi permasalahan maupun potensi yang ada di sekitar masyarakat, meliputi proses mimilih dan mengambil sebuah keputusan, baik alternatif solusi untuk menangani masalah maupun proses pelaksanaan mengatasi masalah serta keterlibatan dalam hal mengevaluasi perubahan yangterjadi, berdasarkan uraian di atas maka dapat disimpulkan selain adanya faktor internal adapula faktor eksternal yang memengaruhi peranan pemerintah desa dalam hal ini partisipasi masyarakat. Partisipasi masyarakat yang kurang aktif akan mengakibatkan sumber daya manusia yakni pemerintah desa juga kurang peka terhadap permasalahan sekitar.

\section{Konsep Implementasi Kebijakan}

mplementasi berasal dari bahasa Inggris yaitu implement yang berarti mengimplementasikan, implementasi merupakan penyediaan sarana untuk melaksanakan sesuatu yang menimbulkan dampak atau akibat terhadap sesuatu, sesuatu tersebut dilakukan untuk menimbulkan dampak atau akibat itu dapat berupa undang-undang, peraturan pemerintah, keputusan peradilan dan kebijakan yang dibuat oleh lembagalembaga pemerintah dalam kehidupan kenegaraan.Winarno (2012:149) memberikan pandangannya tentang implementasi dengan mengatakan bahwa secara umum, tugas implementasi adalah membentuk suatu ikatan (linkage) yang memudahkan tujuantujuan kebijakan bisa direalisasikan sebagai dampak dari suatu kegiatan pemerintah. Mazmanian dan Sabatier dalam Agustino (2008:139) mendefinisikan bahwa implementasi kebijakan merupakan pelaksanaankeputusan kebijaksanaan dasar yang biasanya dalam bentuk undangundang, namun dapat pula berbentuk perintah-perintah atau keputusan-keputusan eksekutif yang penting atau keputusan badan peradilan. Model Implementasi oleh Goerge C. Edward III Model implementasi kebijakan yang berspektif top down yang dikembangkan oleh George C.

a. Komunikasi

kerjakan dapat berjalan apabila komunikasi berjalan dengan baik, sehingga setiapkeputusan kebijakan dan peraturan impelementasi harus ditansmisikan (atau dikomunikasikan) kepada bagian personalia yang tepat, selain itu, kebijakan yang dikomunikasikan pun harus tepat, akurat, dan konsisten.

b. Sumber daya

Sumber daya merupakan hal penting lainnya dalam mengimplementasikan kebijakan, menurut Goerge C.Edward III 
terdiri dari beberapa elemen, yaitu; Staf, Informasi, Wewenang dan Fasilitas.

c. Disposisi

Disposisi Variabel ketiga yang mempengaruhi keberhasilan implementasi kebijakan adalah disposisi,hal-hal penting yang perlu dicermati pada variabel disposisi, menurut Goerge C.Edward III adalah: Pengangkatan birokrat dan Insentif.

d. Birokrasi

Birokrasi sebagai pelaksana sebuah kebijakan harus dapat mendukung kebijakan yang telah diputuskan secara politik dengan jalan melakukan koordinasi dengan baik. Dua karakteristik, menurut Edward III, yang dapat mendongkrak kinerja struktur birokrasi/organisasi kearah yang lebih baik, yaitu dengan melakukan: Standar Operating Prosedures dan Fragmentasi.

\section{B. METODE PENELITIAN}

Penelitian ini menggunakan metode penelitian deskriptif kuantitatif yang bertujuan untuk menjelaskan secara sistematik gejalagejala emperis dan menguraikan hubungan antara variabel bebas (independen) dengan variabel terikat (dependen). Adapun populasi dalam penelitian ini adalah keseluruhan jumlah penduduk yang ada di Kecamatan Maritengngae dengan jumlah 49.556 jiwa sedangkan teknik penarikan sampel menggunakan Random Sampling atau sampel acak, selanjutnya teknik pengambilan sampel dengan taraf kesalahan 10\% menggunakan rumus slovin sebanyak 100responden.Adapun teknik pengumpulan data yang digunakan yaitu obsevasi, kuisioner, wawancara dan studi kepustakaan dengan teknik analisis data yaitu menggunakan table frekuensi dan SPSS 16 for windows.

\section{HASIL DAN PEMBAHASAN}

\section{Peranan Pemerintah}

\section{a. Problem Solver}

Kemanpuan pemerintah Kecamatan Maritenggae untuk menyelesaikan setiap masalah penyalahgunaan Narkoba yang ada di Kecamatan Maritengngae. Dari hasil skor rata-rata sehingga diperoleh persentase sebesar 47,8\% dengan kategori "Cukup Baik".

b. Sebagai Fasilitator
Pemerintah Kecamatan Maritengngae mampu menyediakan fasilitas untuk memudahkan masalah penyalahgunaan Narkoba yang dihadapi masyarakat di Kecamatan Maritengngae. Dari hasil skor rata-rata sehingga diperoleh persentase sebesar 50,8\% dengan kategori "Cukup Baik".

c. Penghubung Antar Sistem

Pemerintah Kecamatan Maritengngae sebagai penghubung untuk memudahkan menyelesaikan masalah penyalahgunaan Narkoba yang di hadapi masyarakat di Kecamatan Maritengngae. Dari hasil skor rata-rata sehingga diperoleh persentase sebesar $47,8 \%$ dengan kategori "Cukup Baik".

d. Sebagai Pemberi Motivasi

$$
\text { Pemerintah }
$$

Kecamatan Maritengngae mengarahkan masyarakat untuk menyelesaikan masalah penyalahgunaan Narkoba yang ada di Kecamatan Maritengngae.Dari hasil skor rata-rata sehingga diperoleh persentase sebesar $46,4 \%$ dengan kategori "Cukup Baik".

e. Sebagai Komunikator Seseorang Maritengngae yang menyampaikan informasi pemerintah terhadap penyalahgunaan narkoba di Kecamatan Maritengngae. Dari hasil skor rata-rata sehingga diperoleh persentase sebesar 45,6\% dengan kategori "Cukup Baik".

\section{Implementasi Kebijakan}

\section{a. Komunikasi}

Kejelasan informasi yang diberikan oleh pemerintah Kecamatan Maritengngae mengenai penyalahgunaan narkoba di Kecamatan Maritengngae. Dari hasil skor rata-rata sehingga diperoleh persentase sebesar $37,2 \%$ dengan kategori "Kurang Baik".

b. Sumber daya

Keahlian pemerintah Kecamatan Maritengngae dalam memberantas peredaran narkoba di Kecamatan Maritengngae. Dari hasil skor rata-rata sehingga diperoleh persentase sebesar $36,6 \%$ dengan kategori "Kurang Baik".

c. Disposisi

$$
\text { Pemerintah }
$$

Kecamatan Maritengngae dalam membetuk lembaga untuk mencegah penyalahgunaan narkoba di Kecamatn Maritengngae. Dari hasil skor rata-rata sehingga diperoleh persentase 
sebesar 45,6\% dengan kategori "Cukup Baik".

\section{d. Birokrasi}

Pemerintah

Maritengngae

Kecamatan

pemberantasan narkoba di Kecamatan Maritengngae. Dari hasil skor rata-rata sehingga diperoleh persentase sebesar $39,4 \%$ dengan kategori "Kurang Baik".

\section{SIMPULAN}

Berdasarkan hasil penelitian dan pembahasan yang telah diuraikan, dapat disimpulkan bahwa:

1. Dari hasil analisis olah data tabel frekuensi variabel $X$ dan variabel $Y$ yang dilakukan, dapat disimpulkan berdasarkan tanggapan responden yang menunjukkan bahwa indikator dari variabel $X$ (peranan), maka diperoleh hasil rata-rata persentase, yaitu $47,68 \%$ atau berada dalam kategori "Cukup Baik" sedangkan akumulasi hasil rata-rata persentase dari empat item pertanyaan pada indikator dari variabel $Y$ (Impementasi) maka diperoleh hasil ratarata persentase, yaitu $39,7 \%$ atau berada dalam kategori "Kurang Baik".

2. Faktor-faktor yang memengaruhi peranan pemerintah dilihat dari faktor yang pertama yaitu faktor internal memiliki pengaruh sebesar 31\%. Faktor yang ke dua yaitu faktor eksternal memilikipengaruh sebesar $50,6 \%$.

\section{E. REFERENSI}

1. Buku :

Ahmad, Jamaluddin. 2015. Metode Penelitian Administrasi Publik (Teori dan Aplikasi). Gavamedia. Yogyakarta.

Arikunto, S. 2010. Prosedur Penelitian Suatu Pendekatan Praktik. Rineka Cipta. Jakarta

A. G, Subarsono.2013. Analisis Kebijakan Publik. Pustaka Pelajar. Yogyakarta.

Budi Winarno. 2012. Kebijakan Publik Teori, Proses, dan Studi Kasus. CAPS.Yogyakarta.

Dunn, William. 2013. Pengantar Analisis Kebijakan Publik. Gadjah Mada University Press. Yogyakarta.

Darma Tri

Nugraha, PeranPemerintahDesadalamtatakelo lasampah di Sereang, 2019.
Gitosaputro,S\&Rangga,

K.K.

2015.PengembangandanPemberday

aan

Masyarakat;

Konsep,TeoridanAplikasinya

EraOtonomiDaerah:Grahallmu;

Yogyakarta.

Ling, K. C., \&Abzakh, A. A. 2012. The Impact

of Experiential Marketing and

Customer Satisfaction on Customer

Commitment in the World of Social

Networks.Asian Social Science,9(1), 262.

Labolo, Muhadam, 2010, MemahamillmuPemerintahan, Rajaw aliPers, Jakarta.

DwiNarwoko,

J.2006.

SosiologiTeksPengantardanTerapan

.Kencana Media Group. Jakarta.

Ndraha,

$\mathrm{T}$.

2010.

TeoriBudayaOrganisasi.PenerbitRin ekaCipta. Jakarta

Noor, Juliansyah. 2011. "MetodePenelitian :Skripsi, Tesis, Disertasi, danKaryallmiah". KencanaPrenada Media Group. Jakarta.

Nurhayati, M. 2013.Profitabilitas, Likuiditas, danUkuran

Perusahaan

PengaruhnyaTerhadapKebijakanDivi dendanNilai Perusahaan Sektor Non Jasa.JurnalKeuangandanBisnis, Vol. 5, No. 2

Slavin, Robert E. 2009.Cooperative Learning Teori, RisetdanPraktik.NusaMedia. Bandung

Soekanto,

Soerjono.2012.SosiologiSuatuPenga ntar. RajawaliPers, Jakarta.

Sugiyono.2009. Metode Penelitian Kuantitatif, Kualitatif dan R\&D. Alfabeta. Bandung.

2011. Metode Penelitian Kuantitatif Kualitatif DAN R\&D (cetakan ke- 14). Alfabeta. Bandung. 2014. Metodelogi Penelitian Kuantitatif, Kualitatif Dan R\&D. Alfabeta. Bandung.

2015. Metode Penelitian Pendidikan Pendekatan Kuantitatif, Kualitatif Dan R\&D. Alfabeta. Bandung. 
Siregar, Syofian. 2015. Statistika Terapan untuk Perguruan Tinggi. PT Kharisma Putra Utama. Bandung.CAPS.

\section{Dokumen}

Peraturan Daerah (PERDA) Kabupaten Sidenreng Rappang Nomor 2 Tahun 2014 Tentang Pencegahan dan Penanggulangan terhadap Penyalahgunaan dan Peredaran Narkotoka dan Psikotropika.

UU Nomor 35 Tahun 2009 TentangNarkoba Pasal 1 ayat (1) Undang-undang Republik Indonesia Nomor 35 Tahun 2009 Tentang Narkotika).

Widiastuti, P. (2018). Implementasi Undangundang No 6 Tahun 2014 Tentang Badan Usaha Milik Desa di Desa Tanete Kecamatan Maritengngae Kabupaten Sidenreng Rappang. Skripsi IImu Administrasi Publik.

\section{Al-Qur'an}

Surah al-maidah ayat 90 . 